\title{
Irma Duraković
}

\section{IZMEĐU JAVE I SNA: NARCISOIDNI SAN U PRIPOVIJECI VRT SPOZNAJE LEOPOLDA VON ANDRIANA}

Pripovijetka Vrt spoznaje (1895) austrijskog autora Leopolda von Andriana obojena je snovitom atmosferom i kao takva ukazuje na značaj fenomena sna u krugu autora bečke moderne još prije nego što će Freudova revolucionarna studija Tumačenje snova (1900) služiti piscima i kao šablon za književne snove. Erwin, junak ove pripovijetke, iako putuje gradovima, ne upušta se u život i protivi se snu, a njegovo opažanje vanjskog svijeta je "narcisoidno". Erwin je u potrazi za spoznajom svijeta, međutim, njegov pogled na putu k spoznaji postaje sve subjektivniji, što rezultira i susretom s njegovim dvojnikom. Ta se njegova borba s dvojnikom ne odvija u snu, nego u snovitoj stvarnosti. U ovom radu postavlja se pitanje šta je snovita stvarnost, zašto Erwin bježi k njoj i koje posljedice ostavlja na njegovo $J a$ te na percepciju svijeta koji ga okružuje.

Ključne riječi: Leopold von Andrian, bečka moderna, san u književnosti, neuroza, percepcija, snovita stvarnost, dvojnik

\section{UVOD: NEKOLIKO BILJEŠKI O FENOMENU SNA}

Neko je sanjao kako mu se govori: "Ne plaši se što ćeš umrijeti, ali nećeš moći dalje ni živjeti." Muškarac je oslijepio [...] on nije umro, ali nije ni živio budući da nije mogao vidjeti svjetlo.“ (Artemidor, 1979, str. 340) ${ }^{1}$

Kao što ovaj primjer iz Knjige snova (2. p. Kr.) Artemidora iz Daldisa svjedoči, snovi su se u antici tumačili kao proročanstva ili božije poruke. Pored predskazanja sudbine koja se obistinjuje, u Artemidorovom tumačenju snova evidentan je rascjep između opažanja u realnom i onog u sanjanom svijetu. Muškarac koji je oslijepio, a nije umro, doživljava ipak neku

${ }^{1}$ Bilješke, pisma i pripovijetke u nastavku teksta s njemačkog prevela I. D. 
vrstu smrti budući da bez vida, kako se u zapisu navodi, ne postoji stvarni život. Međutim, upravo u činu zatvaranja očiju, sanjar noću uočava drugi svijet koji je isto tako "realan" kao onaj pred otvorenim očima. Izuzimajući takozvane lucidne snove u kojima sanjar svjesno sanja i tako u svom snu svjesno oblikuje svoj unutarnji svijet, "ne-svjesni” san je sve do onog trenutka dok se sanjar ne probudi, stvaran kao i sam život. San koji ne poznaje fizikalne zakone, prostorno-vremenske relacije, koji sjećanja i osobe stavlja u krive redove i uloge, sastavni je dio života, ma koliko on varljiv bio. U snu se nadalje regeneriraju tijelo i "duša"; san, dakle, prerađuje ostatke prethodnog dana, strahove, razočarenja ili radosne trenutke. Iz fiziološko-psihološke perspektive on omogućuje život. A u slučaju oslijepljelog sanjara, on također pruža doživljaj podjednako vidljivog svijeta.

Dok Artemidor iz snova iščitava božije poruke, kao što je slučaj i u Homerovoj Ilijadi i Odiseji ${ }^{2}$, već kod Aristotela nailazimo na psihološko razumijevanja sna. Aristotel koji slike snova povezuje s tragovima sjećanja, želi ih objasniti psihološkim putem i prirodnim uzrocima. Tako je, prema njemu, san u povezanosti s "kozmičkim zbivanjem" koje sanjar zbog jakih vanjskih podražaja u budnom stanju mnogo manje opaža nego u snu (Binswanger, 1928, str. 35).

San koji Grci uglavnom tumače kao božije poruke, doživljava reinterpretaciju u srednjem vijeku: umjesto bogova sada anđeli i demoni figuriraju kao glasnici, čime se tumačenje snova naslanja, između ostalog, na astrologiju i praznovjerje. Tek će se u prosvjetiteljstvu sa J. G. Herderom prvi put raspravljati o poetološkoj funkciji sna te će se on tretirati kao estetska kategorija i proglasiti uzorom pjesništva (Ibidem, str. 38). Svoj vrhunac, međutim, san doživljava u romantizmu u kojem postaje ključ za spoznaju svijeta. Psihijatar i psihoanalitičar Ludwig Binswanger u svojoj studiji Promjene u razumijevanju i tumačenju sna (1928) zapisat će da se kod romantičara, a najprije kod Novalisa, prepoznaje "dvostruki pogled" u razumijevanju sna. Pritom u prvom planu nije samo "smjer spoznaje" nego više "preobrazba Ja u vanjske objekte i ponovno uzimanje toga natrag $u$

\footnotetext{
${ }^{2}$ San u antičkoj književnosti fungira i kao sredstvo "lične, skoro [...] personalne spoznaje istine", dakle kao "karakterizacija čovjeka", kako u svom članku ističe Joachim Latacz. Vidi: Funktionen des Traums in der antiken Literatur. U: Traum und Träumen. Traumanalysen in Wissenschaft, Religion und Kunst. Ur. Therese Wagner-Simon u. Gaetano Benedetti, Göttingen: Vandenhoeck \& Ruprecht 1984, S. 25.
} 
vlastito Ja" (Ibidem, str. 40). San, a to mu je najzad i ključna uloga, uči kako da se subjekt uživi i pretvori u sve moguće objekte, pritom uvijek pokazujući isključivo onoga ko sanja, što će Sigmund Freud kasnije ponovo otkriti i snu pripisati narcisoidni doživljaj par excellence. Ali spoznaja svijeta ne leži jedino skrivena u snu, nego i u javi: u smislu samootkrivanja, san proročki pokazuje ono "što u budnom stanju ne znamo ili uopće ne možemo znati" (Ibidem). Fascinacija koja proizlazi iz fenomena sna temelji se i u njegovom načinu izražavanja: njegovom slikovitom jeziku. Slično pjesniku, sanjar imaginira svoj svijet u slikama, on "izmišlja” i pripovijeda priče. Pošto, za razliku od pjesništva, njega odlikuje haotična priroda, jer je san bez oblika i ne slijedi uvijek zakone kauzalnosti - njegove slike, u trenutku kada se izgovore i time pretoče u jezik, postaju nalik bajkovitoj, fantastičnoj a manje nekoj smislenoj priči.

U drugoj polovici 19. stoljeća, u kojem istraživanje o snu doživljava kopernikanski obrat kroz prirodno-znanstveno i psihološko istraživanje njegovih fenomena, lični snovi istraživača stavljaju se pod lupu. Kako bi se san razumio i mogao tumačiti na drugim ljudima, najprije je bilo neophodno isti taj fenomen ispitati na samom sebi. ${ }^{3}$ Pored velikog znanstvenog interesovanja za fenomen sna koji će svoj vrhunac doživjeti u teorijama Sigmunda Freuda i njegovoj psihoanalizi, snovi postaju značaji i u književnosti bečke moderne, ne samo kao tema nego i kao model u smislu prikaza snovitog. Tako se sama stvarnost, kao što književni tekstovi pokazuju, većinom doživljava kao san. Prema tome se postavlja pitanje zašto književni junaci autora bečke moderne sanjaju i zašto tamo, gdje širom otvorenih očiju promatraju fiktivni svijet, stvarnost doživljavaju kao san? Na primjeru pripovijetke Vrt spoznaje (1895) autora Leopolda Andriana u nastavku ovog rada pobliže će se sagledati književna konstrukcija ovih svjetova i okolnosti koje ih određuju.

\footnotetext{
${ }^{3}$ Istraživanje sna tih se godina razvija u Wrocławu, Tübingen, Beču i Leipzigu. 1874. godine paralelno se objavljuju studije njemačkog psihologa Wilhelma Wundta Osnove fiziološke psihologije i filozofa Ludwiga Strümpella Priroda i nastajanje snova. Godinu dana kasnije filozof Johannes Volkelt objavljuje svoju knjigu Fantazija-sna koja se naslanja na studiju Život sna (1861) Karla Alberta Schernera.
} 


\section{LEOPOLD VON ANDRIAN: PISAC I HIPOHONDAR U VREMENU MODNOG LUDINA}

Leopold Reichsfreiherr Ferninand von Andrian zu Werburg - kao pjesnik uzima građansko ime Leopold Andrian dok ga prijatelji nazivaju Poldi rođen je 1875. godine u Berlinu, a već u ranim godinama svog života pridružuje se krugu autora Mladog Beča. U septembru 1893. godine Andrian upoznaje Hugu von Hofmannsthala s kojim će ga godinama vezati prisno prijateljstvo o čemu svjedoči i njihova opsežna korespondencija. Hofmannsthal uvodi Andriana u književni krug Mladog Beča ${ }^{4}$, a sam Andrian već od početka njihovog poznanstva povjerava svom drugaru dileme lične $i$ književne prirode, što će za njega doživotno biti od velikog značaja. Međutim, unatoč povezanosti s njegovim samo godinu dana starijim i u književnom krugu već priznatim prijateljem Hofmannsthalom, u Andrianovim dnevnicima pronalazimo bilješke u kojima se on uspoređuje sa Hofmannsthalom te istovremeno iskazuje sumnju u sebe. Tako u novembru 1895. godine on bilježi:

Ne može se poreći da je on [Hofmannsthal] mnogo savršeniji, skoro da sam rekao, mnogo nadareniji od mene. Jer otkako ga znam, on je uvijek takav, mogao bih pomisliti da je uvijek bio takav, ali s druge strane ipak primjećujem u onome što on piše kako se on dalje razvija, u istom pravcu kao i ja. [...]

Ali u odnosu na mene, svaka razvojna faza jeste donekle samo jedna strana njegove bogate duše koju on njeguje, dok je kod mene u pitanju samo manija u kojoj sam zarobljen i koja prema svemu drugome nosi gađenje. (Andrian, 2003a, str. 58)

U istom mjesecu Andrian postaje određeniji i bilježi:

Kada smo išli s Goldom, primijetio sam da H. toliko mnogo zna [...]. Vidim kako se u filozofiju mnogo bolje razumije od mene (kako njemu matematička strana ne nedostaje mnogo kao meni ) - Kada govori, onda je on taj koji pogodi u srž onoga što je bitno - također i onaj koji kazuje najsmješnije

\footnotetext{
${ }^{4}$ Također, treba napomenuti da je Andrian imao i kontakt s Georgeovim krugom. Od 1893. do 1895/6. on objavljuje devet pjesama u Georgeovom časopisu "Blätter für die Kunst", a njegov Vrt spoznaje bit će pozitivno prihvaćen u ovom krugu. (Renner 1981, 25/6) Odnos između Hofmannsthala i Andriana s jedne strane, i Georgeovogo kruga s druge strane vidi: Thomas Karlauf - Stefan George, 2008. Die Entdeckung des Charisma. Biographie. München: Pantheon.
} 
stvari, on je taj koji većinom stoji iznad svih, koji nikada ništa neće reći što kao pjesnik ne bi smio reći; sigurno bi svako ko je nas 5 sinoć vidio, morao smatrati njega daleko najsavršenijim. (Ibidem, str. 61)

Kako što ovi zapisi i njegova druga pisma dokumentiraju, Andrian prema Hofmannsthalu ima ambivalentan odnos koji je i rezultat njegove sumnje u samoga sebe kao pjesnika. Tako će na jednom mjestu zapisati da on gaji nepovjerenje prema "svemu značajnom, nepovjerenje prema samome sebi” (Andrian, 2003, str. 53). Sve do 1900. godine, kada se odlučuje za diplomatsku karijeru te istovremeno distancira od svog književnog i prijateljskog kruga, Andrian počinje pojačano patiti od neurotičnosti i depresije, zbog čega mu Hofmannsthal savjetuje da apsolvira dobrovoljački vojni rok. ${ }^{5}$ Već 1898. godine, nakon što je dodijeljen 5. dragunskoj pukovniji u Sambotelu (Andrian, 2003, str. 27), Andrianovo stanje rapidno se pogoršava. Iste godine, 20. novembra, Hofmannsthal mu piše:

Kada sam ti hitno savjetovao da odslužiš dobrovoljački vojni rok, tada nisam zaboravio da određena opasnost od porasta samoprezira leži u tome što ćeš fizičke stvari raditi naporno i loše jer niti si jak niti spretan [...] nadao sam se [...] da će kod tebe, međutim, u neurastenično povećanoj svijesti i kritici sopstvenog bića, uslijediti promjena kroz neprestanu prisilnu pozornost na službeni rad. (Hofmannsthal/Andrian, 1968, str. 121)

I pisac Arthur Schnitzler u ulozi svog primarnoga zanimanja bit će kao ljekar uključen u ovaj slučaj i Andrianu davati savjete, što proizlazi iz pisma u kojima Andrian vrlo precizno protokolira svoje duševne i fizičke tegobe. U jednom od prvih pisama datiranom 11. septembra 1897. godine, Schnitzler piše Andrianu: "Vi ste pravi hipohondar! Pri čemu ne želim poreći da i sama hipohondrija nije bolest.” (Andrian, 2003, str.79) ${ }^{6}$ Međutim, još dva mjeseca ranije, Andrian, koji je prema ljekarima vrlo skeptičan te se, između ostalog, uvijek žali na depresiju ${ }^{7}$, u svom dnevniku sam sebi

\footnotetext{
${ }^{5}$ Vidi ovdje i pisma Hermanna Bahra upućena Hofmannsthalu koji također iskazuje svoju zabrinutost zbog Andriana i njegove depresije. Dana 10. jula 1897. godine Bahr piše: "Našem sirotom Podiju jako je loše. Pati od teške melankolije koja mu, uz svu njegovu veliku depresiju, izaziva svakave imagirne strahove: misli da je sušičav, misli da već umire i govori kako neprestano ima vrućicu." (Hoffmannsthal/Bahr, 2013, str. 85/6)

${ }^{6}$ Vidi ovdje i pismo Arthura Schnitzlera datirano 8. novembra 1897. godine (Ibidem, str. 76-78)

${ }^{7}$ Tako npr. zapis iz februara/marta 1896. godine: "Danas je bio najlošiji dan. Mislim da ludim. Kao neki crni veo ispred mojih očiju. Ništa ne vidim. Najdublja depresija.
} 
postavlja pitanje šta je to zapravo hipohondrija. ${ }^{8}$ Iako je teško, kako Walter Perl piše, ustanoviti jasne uzroke Andrianovih duševnih tegoba, ne bi se trebala isključiti niti činjenica da je znatnu ulogu odigrala i njegova "invertirana konstitucija” (Perl, 1969, str. 25). Mada Andrian svoju ambiciju da se "što prije popne stepenicama k. u. k. diplomatske karijere" (Andrian, 2003, str. 93) vrlo brzo i ostvaruje, on ipak nadalje pokazuje sklonost prema hipohondriji koja će ga i za vrijeme njegove diplomatske karijere voditi u Beč ljekaru Schnitzleru.

Vanjski život, požaliti će se Hofmannsthalu, izaziva u njemu povećanu nervozu. "Mislim da sam veliki umjetnik", napisat će Andrian, "ali jako mi je loše" (Andrian, 2003, str. 93). Upravo moderna nervoza, kako književnik Egon Friedell piše, jeste ta koja je vezana za "povećanu perceptibilnost podražaja: ona je bogatija i smjela sposobnost asocijacije: duh" (Fridell, 1992, str. 79). Rano sazreli pjesnik (Perl, 1969, str. 23) koji svoju književnu produktivnost uspoređuje s onom svojih prijatelja, a pritom potiskuje svoje homoseksualne sklonosti ${ }^{9}$, vrlo će brzo zanijemiti na književnom polju. Nakon objavljivanja svoje pripovijetke Vrt spoznaje (1895) Andrian iste godine 22. septembra piše Hofmannsthalu:

I ja sam se promijenio, to je promjena koja se desila odmah nakon moje prve knjige, a koja ipak nije sasvim presudna ili gotova; [...]. Jako sam se promijenio i to tako brzo da sam skoro tužan zbog toga, a zasigurno i začuđen. (Hofmannsthal/Andrian, 1968, str. 56)

Andrian u svojoj pripovijetki Vrt spoznaje obuhvata "cijeli grad s gledišta pojedinca" u potrazi da osjeti bit stvari, međutim, na drugo lice stvari on se namjerno ne osvrće, "namjerno se nije htio osvrtati, nizašta ga pogledati [...]” (Hofmannsthal, 1980, str. 410). U ovom Hofmannsthalovom zapisu iz Poldyjevog vremena Horst Schumacher vidi jasnu aluziju utjecaja Vrta spoznaje na Hofmannsthalovu Bajku 672. noći, koja istovremeno

\footnotetext{
Permanentni osjećaj ropstva. To je kao neka borba, kao kada čovjeka nešto uhvati za grkljan i drži ga, a zatim postaje lakše, ruka se opusti oko vrata" (Andrian, 2003, str. 64). ${ }^{8}$ Vidi ovdje zapis iz septembra 1897. godine: Leopold von Andrian (1875-1951). Korrespondenzen, Notizen, Essays, Berichte, op. cit, str. 79.

${ }^{9}$ To se jasno vidi i iz pisama upućenih Hofmannsthalu. Andrian često iskazuje velike simpatije prema prijatelju zbog ćega će se Hofmannsthal vremenom distancirati od njega. Vidi ovdje pisma 17. juna i 17. jula 1895. godine. (Hofmannsthal/Andrian, 1968, str. 49-51).
} 
nastaje i u kojoj se vidi "takoreći izvjesno natjecanje ova dva pjesnika" (Schumacher, 1967, str. 52). Schumacherova teza temelji se na usporedbi svjetonazora glavnih likova ove dvije pripovijetke i njihovog karakterističnog stanja: udaljenosti i otuđenosti od života te snovitim i bajkovitim postojanjem. Ovaj svjetonazor Schumacher sažima u pojam ne-stvarnosti. Ukoliko likovi, kako autor dalje veli, nisu dorasli životu, oni se povlače u nutrinu i žive u svijetu stvorenom od snova. Schumacher time "snovitost bitka" u pripovijetki svodi na nemogućnost poimanja stvari budući da one same proizlaze iz snovite stvarnosti. Međutim, postavlja se pitanje: Šta je to u Andrianovoj pripovijetki snovita stvarnost? Za razliku od bezimenog junaka, trgovačkog sina u Hofmannstalovoj Bajci 672. noći, Andrian svom liku daje ime i pokazuje proces njegovog prividnog "razvoja", pritom se fokusirajući na prikaz njegovog unutarnjeg života, a ne i vanjskog zbivanja. Andrianov Vrt spoznaje je, ocijenit će pisac Ferdinand von Saar, “obilje atmosfere i osjećaja, farbi i tonova" (Rieckmann, 1985, str. 66), dok Felix Salten u svojoj rezenciji ističe kako priča uvodi u najbitnije "trenutke duše" (Ibidem).

Koliko je unutarnjost i samom autoru bitna, svjedoči Andrianovo pismo Hofmannsthalu u kojem mu piše da postoji nešto u "vanjskom životu" što se može pojmiti tek "ludilom duše" (Hofmannsthal/Andrian, 1968, str. 37). Baš kao što Andrian svoj vanjski život doživljava na ekstremno subjektivan način, čini se da isto to "ludilo duše" o kojem izvještava Hofmannsthala, pronalazi svoj put u pripovijetku i zaustavlja se u njegovom liku Erwinu.

\section{NAGON SPOZNAJE I NARCISOIDNA SLIKA O SVIJETU}

Poetika dekadencije je, napisat će Hermann Bahr u svom eseju Die Décadence (1891), patološka poetika - jedna nova "moda ludila" (Bahr, 2006, str. 26). Bahr je naziva nervoznim romantizmom pošto ona poput romantičara traži nutrinu čovjeka koju ne želi izraziti duhom i osjećajem, nego nervima (Ibidem, str. 27). U svom programu o Prevladavanju naturalizma (1891) Bahr proklamira da nova umjetnost mora:

(...) vlastito [oblikovati] iz same sebe umjesto da oponaša strano, tražiti tajanstveno umjesto da slijedi očigledno kako bi izrazila upravo ono u čemu 
se drugačije osjećamo i drugačije poznajemo od same stvarnosti. (Bahr, 2004, str. 129)

Bahr razumijevanje nove umjetnosti također tematizira u eseju Die Moderne, koji će nakon svog putovanja u Pariz objavit 1. januara 1890. godine u prvom broju mjesečnika Moderne Dichtung (Daviau,1894, str. 70). Bahrov esej Die Moderne, piše Gotthart Wunberg, nalikuje više konferenciji, "monologu bogatom asocijacijama", u kojem autor s publikom dijeli strah za "budućnost književnosti” (Wunberg, 1976, str. LIV). "Mi želimo postati stvarni”, piše Bahr, "[mi] želimo biti pokorni vanjskim zapovijedima i unutarnjoj čežnji” i “[mi] želimo postati što je postala naša okolina” (Bahr, 2004, str. 12). Bahr u tekstu pokazuje da život i umjetnost čine trojstvo, upravo kao što trojstvo čini i istinu: jedna istina je u tijelu, jedna u osjećaju, a jedna je u mislima.

Iako se prema Wunbergu Bahr u kontekstu istine još uvijek nalazi u "neposrednoj blizini naturalista" (Wunberg, 2001, str. 196), on se ipak udaljava od njih kada o istini govori kao o zakonu koji svako osjeća. Umjetnik treba služiti samo istini: on mora biti poslušan vanjskom svijetu kako ne bi i dalje bio stranac u njemu, iako je ovaj "nasilan a često zloban i okrutan". I on najzad mora učiniti da "vanjsko postane unutarnje" (Bahr, 2006, str. 13). Bahra zakon o objektivnoj istini, dakle, i ne zanima, već samo subjektivna istina kakvu je "svako osjeća" (Ibidem, str. 14). Iako se Bahrova nova umjetnost poziva na istinitost $\mathrm{u}$ prikazu te se vezuje za poetski koncept naturalista, on u ovoj novoj formi uvodi "subjekt kao kritičku instancu" (Wunberg, 2001, str. 197). Istina, o kojoj Bahr piše i koja se nalazi u vanjskom svijetu, treba pronaći svoj put u dušu, i to preko osjetila i nerava. Ta istina, koja se "preobrazi u duševno, koja usvoji jezik duše", stvara najzad "jasne simbole" (Bahr, 2006, str. 14). Bahr će nadalje napisati da se estetika pomjera iz tržnice stvarnosti u hram sna, pa time i otvoriti pitanje značaja sna za književnost na prijelomu stoljeća te ujedno ukazati na njenu proturječnost. U svom eseju Sotonizam (1894) on bilježi:

Duh ljudi isti je kao bolesnik koji leži u vrućici: on neumorno okreće jastuke. [...] Duh se povjerio snovima i ništa se nije desilo. Iz snova je otišao $\mathrm{u}$ istinu, u stvarnu istinu svakodnevnog života, i opet se ništa nije desilo. Sada vječito ponovo luta tražeći snove i opet se ništa neće desiti. (Bahr, 2006, str. 115-116) 
Put iz zbilje u san, odnosno iz vanjskog života u nutrinu, treba da artikulira istinu onakvu kakvu je subjekat percipirajući reflektira. Ali čini se kako taj put nije jednostavan budući da duh neprestano luta između ova dva svijeta. Za istinom traga i Andrianov lik Erwin koji želi spoznati svijet iako on letargično prolazi kroz svoj život. Erwin se ne povlači u izolaciju kao što je to slučaj s Hofmannsthalovim likom iz Bajke 672. noći, ali unatoč tome on je ipak uvijek sam. Nakon svoje prve pričesti, Erwin se odlučuje da postane svećenik jer mir, kako sam veli, dolazi "jedino od Boga”. No pošto život u Bogu ne obuhvata istovremeno i ljepotu svijeta, Erwin spoznaju nadalje traži u "velikom svijetu". Nakon trogodišnjeg studija u Bolzanu on se ponovo vraća u Beč gdje primjećuje:

[Nj]egova raznolikost koja ga je ranije dirala, sada ga je zbunjivala i prijetila mu je. Jednoga jako vrelog dana plašio se muzike koja je bila u svim ulicama; činilo mu se kao da je grad prožet njome poput varljivog otrova koji bi čovjeka trebao učiniti pospanim i nejakim. Drugog dana uplašile su ga oči ljudi: sve su se previše sijale, bile prevelike i preširoko otvorene, a sve su bile usmjerene prema njemu. (Andrian, 2003, str. 35)

Velegrad koji se preobražava u opasnu kulisu usko je povezan s nepoznatim likom kojeg će Erwin triput sresti u Beču. Na svom putu k (samo) spoznaji signifikantno je i Erwinovo sjećanje koje će, međutim, mnogo intenzivnije početi doživljavati na selu. Erwin zna da su sjećanja bila "njegov život" i upravo ta "uzvišena i dragocjena" sjećanja jesu za njega "izvor ljepote" (Ibidem, str. 25).

Jer ljudi čija su ga sjećanja znala ganuti, ganula bi ga samo zato jer je živio u njima, a također su ga znale ganuti kuće na koje bi se otvarao pogled s njegovih prozora, ili ulice kojima bi koračao. Ipak bi ga obuzele usne $\mathrm{i}$ kose mnogih ljudi koje bi susretao; ali on nije govorio s njima i većinom je bio sam. [...] Bilo je prelijepo što nas usamljena smrt koja jeste život, ne može spriječiti da se divimo sretnoj ljepoti, koju ne razumijemo, koja nam se neće otkriti niti nam nešto dati, samo zato jer je lijepa; bilo je prelijepo što mi, iako smo ljudi a ipak umjetnici, umjetnici u tome što se čak i ne žalimo kada nam izmakne ta ljepota, nego je pozdravljamo i zbog nje kličemo pošto nam igrokaz mnogo više znači od same naše sudbine. (Ibidem, str. 31-32)

Dok Hofmannsthalov trgovački sin iz Bajke 627. noći igrokaz života posmatra s distancom i većinom iz svog vrta ili sa svog prozora, Erwin se 
upušta u život. Iako on sam svoju usamljenost uvijek iznova uviđa, Erwin, poput Narcisa, slijedi put k spoznaji svog istinskog Ja, odnosno jedinstva njegovog Ja s drugima (Müller, 1977, str. 96). Budući da njegov poriv za spoznajom postaje sve veći, Erwin odlučuje započeti studij u Beču, ali ni nauka, što će kasnije uvidjeti, u konačnici mu neće moći objasniti svijet. Njemu postaje jasno:

(...) da on u svijetu ne treba tražiti svoje mjesto jer je on sam bio svijet, podjednako velik i podjednako jedinstven kao on, ali studirao je dalje jer se nadao da će mu onda kada je bude spoznao, iz slike svijeta ususret gledati njegova slika. (Andrian, 2003, str. 40)

Upravo se u opažanju vlastite slike kod njega mijenja i opažanje svijeta. Rješenje nekih “tajni svijeta”, piše Rieckmann, Erwinu je upravo onemogućeno zbog njegovog "narcisoidnog Ja” (Rieckmann, 1985, str. 78). Kao u mitu o Narcisu, i sam Erwin umire nakon što se prepozna u alegorijskoj figuri stranca. U konstelaciji narcisoidne potrage za samim sobom u pripovijetki značajnu ulogu zadobiva san kao model egzistencije. Na samom početku ističe se da je Erwin bio usamljen i "sam sebi dovoljan":

Njegovo tijelo i njegova duša vodile su u sebi skoro dvostruki život; stvari vanjskog svijeta imale su za njega vrijednosti koje imaju u snovima; bile su to riječi jednog jezika koji je igrom slučaja bio njegov, ali tek voljom bi dobile značaj, mjesto i boju. [...] Taj život bio je strani posao koji je on morao obavljati, činio ga je umornim a cijeloga dana bi se veselio da krene spavati. (Andrian, 2003, str. 13-14)

Erwin, dakle, temelji svoj život prema logici unutarnjeg igrokaza, kojem tek njegovo Ja daje "značaj, mjesto i boju". Shodno tome, snovita stvarnost može se razumjeti kao analogija veze narcisoidnog $J a$ i njegovog doživljaja svijeta: kao i u snu, njegovo $J a$ stvara svoj vlastiti svijet. Treba pritom napomenuti da se konstrukcija pripovijedanja u Vrtu spoznaje ne orijentira prema modelu sna koji se vrlo često odlikuje vremenskim i prostornim diskontinuitetom, nego se koncentrira na fiksirani pogled estete i na njegovo "vlastito Ja", koje ne dopušta "lični odnos prema drugom" (Paetzke, 1992, str. 37). Iako se Erwin na početku raduje odlasku na spavanje, njegovo ushićenje lagano nestaje u nastavku priče. On se opire snu kako se u njemu ne bi morao boriti protiv svog neprijatelja. Njegov neprijatelj, koji se krije iza maske stranca kojeg susreće u vanjskoj stvarnosti, može se čitati i kao 
"paradigma nesvjesnoga" (Renner, 1981, str. 206), kao dvojnik koji mu stoji na putu.

\section{SLIKA ERWINA}

Erwin triput nailazi na stranca. Prvi put ga susreće početkom proljeća nakon što u šetnji kroz Beč začuje muziku iz „niske kuće“ i odluči se unići u nju. U veselom društvu koje zatiče u jednoj sobi Erwin prvi put vidi lika koji za razliku od drugih, ne dijeli oduševljenje već ostaje ozbiljan.

Sasvim ozbiljan ostao je i Jedan koji je sjedio pored Erwina. On je samo s vremena na vrijeme gledao Erwina, a kada su mu donijeli vino, pružio je čašu Erwinu kako bi najprije on iz nje pio. Kada mu je zatim Erwin dao cigaretu, činilo se kako njegovo tijelo u neobično laskavoj i poniznoj zahvalnosti postaje manje, dok su njegove oči preklinjale, ali mirno gledale u Erwina. A Erwinu, koji mu je gledao u lice, najednom pade na um suprotnost lica voljene sa zatvorenim očima, kao neka maska ispod kacige njene kose boje zlatna u osamljenoj i ponosnoj ljepoti smrti. U prostom licu stranca bijaše blagost i zloba, bojažljivost i prijetnja i cijeli život, ali istovremeno kao u životu; jer ono se ne bi mijenjalo kada bi govorio, samo bi mu se tijelo okretalo kao pod nekim unutarnjim pokretom koji ga je svladavalo. [...] Išli su kroz predgrađe prema kolodvoru, a stranac je pričao svoj život; Erwin je znao da on laže, ali također je znao da u toj laži nekako leži i duboka, tamna, višestruka istina. (Andrian, 2003, str. 30)

Erwin i stranac se rastaju nakon prvog susreta u jednoj uličici. Drugo i treće viđenje, koje je obojeno nestvarnom atmosferom, dešava se "ispred ugla dvaju uličica" u kojima se stranac najednom pojavljuje ispred Erwina. Koliko je stranac Erwinu za petama, pokazuje još i epizoda kada Erwin na svom planinskom izletu prenoći u kući - koja slijedi nakon njihovog prvog susreta - i u toj noći u svojoj sobi posmatra kako se u stanju između jave i sna njegove misli na ljude, koje je nekoć volio, pretvaraju u vizualne slike (Freud, 1975, str. 63):

Oni su pomjerali udove i mamili poglede i smijali se i počeli plesati, a niz figura njihovih plesova pomiješala se sa nizom kuća i soba; u kojima se bijahu njemu podali. Tada je primijetio kako pada u san, a to nije htio; mučno se borio s tim pojavama. (Andrian, 2003, str. 34) 
Odmah zatim on doživljava "optičku varku" i vjeruje da umjesto ogledala vidi prozor ${ }^{10}$ iza kojeg je bilo:

[...] ljudsko obličje i to obličje došlo je zbog njega i čekalo ga je... Ali kada je zapalio svjetlo i osvijetlio zid, tu više nije bilo prozora; ogledalo ga bijaše prevarilo, jedno malo ogledalo iznad čijeg se pozlaćenog okvira spustila mjesečina kada ju je tihi vjetar, koji se bijaše uzdigao, bacio o zid. (Andrian, 2003, str. 34-35)

U trenutku kada se pojavi dvojnik, piše austrijski psihoanalitičar Otto Rank $^{11}$, prepoznaje se i usamljenost. Iako se čini neobičnim to što se "samoća [...] osjeća i prikazuje kao naporno društvo nekog drugog, akcenat se ipak stavlja [...] na druželjubivost sa sopstvenim Ja koje se objektivira kao dvojnik." (Rank, 1925, str. 33) Dvojnik svom uzoru stoji uvijek na putu, zaključuje Rank koji na književnim primjerima analizira kako dvojnik uvijek nalikuje junaku, bilo imenom, glasom, odjećom ili sličnošću u izgledu (Ibidem, str. 47). Signifikantno u ovom kontekstu s gore citiranim pasusom jeste upravo nedostatak opis Erwina i njegovog dvojnika. Niti se opisuje Erwinova vanjština, niti njegova slika u ogledalu dok se, međutim, stranac tokom njihovih susreta jasno karakterizira vanjskim propadanjem. Na primjeru motiva narcisa u romanu Slika Doriana Graya Oscara Wildea Rank konstatira da je Dorianov erotični stav prema vlastitom Ja jedino moguć jer se "odbrambeni osjećaji mogu isprazniti na omraženom i opasnom dvojniku" (Ibidem, str. 100). Tako Jens Malte Fischer ima pravo kada kaže da je i stranac u Vrtu spoznaje slika u koju "Erwin kao i Dorian izbacuje starenje i otvrdnuće" (Fischer, 1978, str. 153). Promjena u liku stranca evidentna je u njihovom drugom susretu u kojem se, kao što je već rečeno, mijenja i Erwinov pogled na grad:

\footnotetext{
${ }^{10}$ Ursula Renner koja u svojoj knjizi psihoanaltičkim pristupom iscrpno analizira pripovijetku, u ovoj slici unutranjeg prostora vidi simbol Erwinovog Ja koje se pokušava osloboditi iz svoje zbunjenosti. Upravo scena s prozorom pokazuje, zaključuje Renner, kako mogućnost oslobađanja propada jer prozor koji ukazuje na povezanost Ja s vanjskim svijetom nestaje, a ono što ostaje jeste Erwinova slika, tj. on sam "ostaje svoj zarobljenik" (Renner, 1981, str. 174/5).

${ }^{11}$ U svojoj psihoanalitičkoj studiji Dvojnik Rank razlikuje figure dvojnika koje postaju "samostalne i vidljive odvajanjem od Ja (sjena, slika u ogledalu)" od onih "stvarnih figura dvojnika koje jedna drugu susreću" u vanjskom svijetu i imaju nevjerovatnu sličnost (Rank, 1925, str. 18).
} 
Iste večeri, kada je izašao iz ugla dviju uličica, stajao je stranac pred njim s kojim je, u proljeće, čeznutljivo išao za spoznajom; stranac ga je ponizno pozdravio; njegovo lice i njegove geste toliko su se međusobno razlikovale i bile tako tajanstvene kao pri prvom susretu, ali sada je izgledao siromašnije, a bojažljiv mir u njegovim očima bio je opasniji. [...] Pod utiskom ovog susreta, Erwinu se u narednom periodu promijenio grad. [...] Drugog dana plašile su ga oči ljudi: sve su se previše sijale, bile prevelike i preširoko otvorene, a sve su bile usmjerene prema njemu. Samo jednom prije svog odlaska bio je jako dirnut. Bilo je to na maloj stanici u blizini Beča: željezničkom stanicom prošao je voz sa čijih prozora su gledali mladi momci koji su pristizali; njihova blijeda lica blistala su a oni su pjevali i imali su svijetlo lišće na svojim plavim Deutschmeister kapama. (Andrian, 2003, str. 34/5)

Slika pohlepnih i beznačajnih očiju velegrađana i muškaraca koji putuju $\mathrm{u}$ vozu, ponovo se javlja u Erwinovom jedinom snu. Prije svoje smrti on sanja:

Jednom je zaspao i sanjao. Tada mu se neko pojavio a on nije tačno znao da li je to bio Clemens ili onaj poručnik s kojim se nekoć vozio u Bolzano, patio je zbog te neizvjesnosti; preklinjući molio je pojavu da se imenuje. Ali ona je nestala. Zatim je Erwin bio na željezničkoj stanici i čekao je; tada je u velikoj buci stigao voz u dvoranu iz čijeg je prozora gledalo mnogo ljudi; imali su lica onih koji putuju, njihova boja bila je bijela a oči su blistale, ali ispod njihovih očiju prostirala se ugljena prašina. Bilo ih je mnogo, jako mnogo i sve koje je poznavao bili su među njima, samo ne i ona žena, a i mnogi dugi bili su tu koje nije poznavao. Zatim su ponovo neobično ličili jedni na druge. I najednom svi su ga nazvali imenom, a on je znao da na taj poziv mora uslijediti spoznaja i bio je vrlo radostan zbog toga. (Ibidem, str. 42)

Kao što njegove slike sna kazuju, riječ je najprije o ostacima prethodnog dana i ključnim doživljajima junaka, kao npr. putovanje. Sa jedne strane, slika putnika povezana je s Erwinovom potrebom za putovanjima pomoću kojih on traži razotkriti tajnu života i priželjkuje uzajamnu igru između "stvari", "bića" i njegovog Ja. Sa druge strane, međutim, vožnja vozom simbolizira i prolaznost života. I u njegovom snu, međutim, spoznaja se jasno vezuje za njegovo $J a$. No tu spoznaju, kojoj se on nadalje nada, Erwin ne uspijeva dosegnuti ni nakon što poznata i nepoznata lica u snu uzviknu 
njegovo ime jer i u snu, kao apsolutnom narcisoidnom prostoru ${ }^{12}$, postoji jedna vrsta željeznog zida između ljudi u vozu (kao životu u kolektivu) i Erwina. Time se nagon za spoznajom može razumjeti jedino kao "projekcija vlastitog ja”. (Renner, 1981, str. 215)

U svojoj studiji Uvod u narcizam (1914) Freud ukazuje na paralele između povezanosti s organskim oboljenjima, u kojima bolesnik svoja "libidna zaposjednuća povlači na svoje Ja kako bi ih ponovo nakon ozdravljenja ispustio van sebe" (Freud, 1975, str. 49), i sa stanjem sna koji također znači "narcisoidno povlačenje pozicije libida na vlastitu ličnost, tačnije rečeno, na želju za snom. Egoizam snova time se može uklopiti u ovu povezanost." (Ibidem, str. 50) Kao što je gore već rečeno, Erwinovo narcisoidno Ja svoju egzistenciju doživljava kao u snu, ali se on sam protivi zaspati. Jedini san koji Erwin sanja zbiva se u stanju vrućice u kojem se on više ne može boriti protiv njega, kao što je to bio slučaj na njegovom izletu na planinama. Indikativno, u Erwinovom snu je činjenica da se stranac, koji mu u njegovoj vanjskoj stvarnosti staje na put, ne pojavljuje u njegovom snu. Tog istog stranca Erwin naziva neprijateljem koji ga, kako zaključuje, može spopasti u snu i zbog kojeg se on najzad i protivi upustiti u svijet snova:

Bio je to strah od snova u kojima na ulicama idemo između mnogo ljudi, i najednom nas spopadne naš neprijatelj $i$ onda se moramo boriti s njim; ali sa obadvije strane idu ljudi dalje i oni nam ne pomažu jer je naš zrak, pošto ga dišemo, drugačiji od njihovog, i oni ne čuju naše vriske i ne vide nas niti našeg neprijatelja, a mi se s njim moramo boriti sami. (Andrian, 2003, str. 41)

Dvoboj sa strancem najzad se održava u vanjskoj stvarnosti, pri čemu je odlučujući posljednji susret u kojem Erwinu najzad postaje jasno da zapravo i ne postoji mogućnost bijega od vlastitog, njemu već neprijateljskog i stranog, $J a$ :

Tada se pred njim na uglu dviju uličica pojavi stranac iz proljeća i ljeta; lice mu bijaše promijenjeno, bio je mršaviji, izobličen i neumoljiv, samo su pokreti njegova tijela ostali isti. Ali sada u njemu nije više bilo primamljivog dvojstva života, ništa u njemu više nije bilo osim grozne prijetnje.

12 "Narcisam stanja u snu", piše Freud u eseju Metapsihološka dopuna učenju o snu (1915), izvodi se iz činjenice da je san "apsolutno egoističan", a "osoba koja u njegovim scenama igra glavnu ulogu može se kao jedina agnoscirati.” (Freud, 1982, str. 180) 
A u njegovom pogledu Erwin je najednom znao ko je bio taj stranac: on je bio njegov neprijatelj, on ga je tražio od njegova rođenja te ga našao u opijenosti proljeća i od tada ga pratio i išao za njim i sve mu bliže prilazio i konačno ga sustigao i položio svoju ruku na njega.... Nije htio kući, i tamo ga je neprijatelj mogao pronaći; trčao je kroz uličice i tek je ujutro došao kući. Narednih dana nije ga napuštao strah a njegova duša postala je strašno osamljena i ništa više nije vidjela od života osim strahovitoga dvoboja sa strancem. (Ibidem, str. 41)

To da Erwin u dvoboju umire nije prepušteno slučajnosti. Kao dijete prebolovao je tešku upalu pluća, te upravo svoju posljednju borbu on otpočinje kišovitoga novembarskog dana dok noću luta ulicama u bijegu od svog drugog Ja. Oslobađanje od dvojnika, tj. od svog vlastitog $J a$, piše Otto Rank, najčešće se dešava "ubistvom dvojnika [...] zapravo samoubistvom - i to u bezbolnom obliku ubistva drugog Ja: nesvjesna iluzija o odvajanju zlog Ja koje jeste vrijedno kažnjavanja i što se, uostalom, čini preduvjetom svakog samoubistva." (Rank, 1925, str. 109) Tjelesnost sna postaje ključna kod Andriana, što se ne pokazuje samo narcisoidnim doživljajem svijeta, nego i u pokušaju da se u vanjskoj stvarnosti Erwin oslobodi svog Ja. Erwin zasigurno jeste primjer narcisa par excellence kojem je igrokaz mnogo stvarniji od samoga života. Od samoga je početka za njega život više san nego njegova sudbina, ali ipak toliko tjelesan i stvaran kako bi se u konačnici mogao izboriti sa svojim dvojnikom. No, ostaje pitanje zašto književni likovi bečke dekadencije ne žele ili ne mogu živjeti svoje živote. Jedino ono što žive, kao što pokazuje primjer Erwina, jesu misli - sjećanja, imaginacije - atmosfere i negativna raspoloženja. Hugo von Hofmannsthal će jasno dijagnosticirati duh vremena koji je iznjedrio likove poput Erwina: to je, po njemu, vrijeme u kojem se razmišlja o mislima, osjećaju osjeti i u kojem se svi bave autopsihologijom, ili, kako u svom trećem D’Annunzio-eseju (1895) vrlo jasno poentira:

Oni [te pojave] bili su poput sjena. Bili su sasvim bez snage. Jer snaga da se živi jeste misterij. Što je snažniji i nadmeniji neko u budnom snu, time može biti slabiji u životu, tako slab da se to jedva može kazati, nesposoban vladati i služiti, nesposoban voljeti i ljubav uzeti [...]. Radnje koje ostavlja za sobom, nisu njegove, riječi koje govore, ne dolaze iz njega, on se nadalje kreće poput utvare među živima, sve prolazi kroz njega kao strijele kroz sjenu i privid. (Hofmannsthal, 1980, str. 163) 


\section{LITERATURA}

Artemidor, D., 1979. Das Traumbuch. München: Deutscher Taschenbuch Verlag. Andrian, L., 2003. "Der Garten der Erkenntnis”. U: Sudhoff, D. ur. Der Garten der Erkenntnis und andere Dichtungen. Oldenburg: Igel.

Bahr, H., 2006. Studie zur Kritik der Moderne. Weimar: VDG.

Bahr, H., 2004. "Die 4. VDG.ritik der Moderne an". Kritische Schriften II. Weimar: VDG.

Binswanger, Č., 1928. Wandlungen in der Auffassung und Deutung des Traumes. Von den Griechen bis zur Gegenwart. Berlin: Springer.

Dengel-Pelloquin, E., 2013. Hugo und Gerty von Hofmannsthal. Hermann Bahr. Briefwechsel 1891-1934, Bd. 1. Göttingen: Wallenstein.

Daviau, D. G., 1894. Der Mann von Übermorgen. Hermann Bahr 1863-1934. Wien: Österreichischer Bundesverlag.

Fischer, J. M., 1978. Fin de Siècle. Kommentar zu einer Epoche. München: Winkler.

Freud, S., 1975. "Zur Einführung des Narzissmus". U: Psychologie des Unbewussten. Studienausgabe. Frankfurt am Main: Fischer.

Fridell, E., 1992. Ecce Poeta. Zürich: Diogenes.

Hofmannsthal, H. v., Andrian, L., 1968. Briefwechsel. Frankfurt am Main: Fischer.

Hofmannsthal, H. v., 1980. "Produktion in der Poldyzeit". U: Reden und Aufsätze I. 1891-1913 aus 1895. Frankfurt am Main: Fischer.

Hofmannsthal, H. v., 1980. "Der neue Roman von D’Annunzio". U: Reden und Aufsätze I. 1891-1913 aus 1895. Frankfurt am Main: Fischer.

Karlauf, Th., 2008. Die Entdeckung des Charisma. Biographie. München: Pantheon.

Latacz, J., 1984. "Funktionen des Traumes in der antiken Literatur". U: Wagner, S., Bendetti, G. Traum und Träumen. Traumanalysen in Wissenschaft, Religion und Kunst. Göttingen: Vandenhoeck \& Ruprecht, str. 10-32.

Müller, K. J, 1977. Das Dekadenzproblem in der österreichischen Literatur um die Jahrhundertwende, dargelegt an Texten von Hermann Bahr, Richard von Schaukal, Hugo von Hofmannsthal und Leopold von Andrian. Stuttgart: Hans-Dieter Heinz Verlag.

Paetzke, I., 1992. "Der Ästhet als Narziß. Leopold Andrian: 'Der Garten der Erkenntnis"' U: Paetzke, I. Erzählen in der Wiener Moderne. Tübingen: Francke, str. 27-51. 
Perl, W., 1969. "Der Dichter Leopold Andrian: Frühvollendung und Verstummen". Modern Austrian Literature, Vol. 2, No. 2, str. 23-29.

Prutsch, U., Zeyringer, K., 2003. Leopold von Andrian (1875-1951). Korrespondenzen, Notizen, Essays, Berichte. Wien - Köln - Weimar: Böhlau.

Rank, O., 1925. Der Doppelgänger. Eine Psychoanalytische Studie. Mit einem Nachwort von Mladen Dolar. Wien: Turia \& Kant.

Rieckmann, J., 1985. Aufbruch in die Moderne. Die Anfänge des Jungen Wien. Österreichische Literatur und Kritik in Fin de Siècle. Köngistein: Athenäum.

Renner, U., 1981. Leopold Andrians 'Garten der Erkenntnis': literarisches Paradigma einer Identitätskrise in Wien um 1900. Frankfurt am Main i dr.: Lang.

Schumacher, H., 1967. Leopold Andrian. Werk und Weltbild eines österreichischen Disters, Wien: Bergland Verlag.

Wunberg, G., 1976. Das Junge Wien. Österreichische Literatur und Kunstkritik 1887-1902, Bd. I: 1887-1896. Tübingen: Niemeyer.

Wunberg, G., 2001. “Thesen zur Wiener Literatur 1900”. U: Dietrich, S., ur. Jahrhundertwende. Studien zur Literatur der Moderne. Zum 70. Geburtstag des Autors. Tübingen: Narr. 


\title{
BETWEEN REALITY AND DREAM NARCISSISTIC DREAM IN THE STORY DER GARTEN DER ERKENNTNIS BY LEOPOLD VON ANDRIAN
}

\begin{abstract}
Summary
The Story Der Garten der Erkenntnis (1895) by the Austrian author Leopold von Andrian is colored by a dreamlike atmosphere and, as such, points to the importance of the dream phenomenon among Viennese modernists even before Freud's revolutionary study Die Traumdeutung (1900) served as a template for literary dreams. Erwin, the protagonist, although travelling through cities, does not embark on life and opposes sleep; his perception of the outside word is "narcissistic". Erwin is in search of knowledge of the world; however, his view on his path to cognition becomes increasingly subjective, resulting in an encounter with his doppelganger. And his struggle with the doppelganger does not take place in his dream, but in his dreamlike reality. In this paper, the question arises as to what the dreamlike reality is, why does Erwin flee to it and what consequences are left on on him and the perception of the world around him.
\end{abstract}

Key words: Leopold von Andrian, Young Vienna, dream in literature, neurosis, perception, dreamlike reality, doppelganger 